Prof. Corneliu-Liviu POPESCU

\title{
Drepturile omului vizate de măsurile derogatorii stabilite prin decretele de instituire / prelungire a stării de urgență
}

\section{Human rights covered by the derogating measures established by the decrees establishing / extending the state of emergency}

\section{Cuvinte cheie}

Drepturile omului. Măsuri derogatorii. Stare de urgență. Lege. Claritatea legii.

\section{Key words} law.

Human rights. Derogations. State of emergency. Law. Foreseeability of the

\section{Rezumat}

Decretele de instituire și de prelungire a stării de urgență conțin un articol privind o enumerare expresă a drepturilor omului vizate de măsurile derogatorii. Deși modul de redactare a textului indică faptul că enumerarea este exhaustivă, în realitate în anexele la decrete și alte drepturi ale omului sunt vizate de măsurile derogatorii. Acest lucru face ca "legea" (în sens european autonom) de instituire a măsurilor derogatorii să fie lipsită de claritate.

\section{Abstract}

The decrees establishing and extending the state of emergency contain an article expressly enshrining the human rights covered by the derogating measures. Although the wording of the text indicates that the list is exhaustive, in reality in the annexes to decrees other human rights are also covered by the derogating measures. This renders the "law" (in the autonomous European sense) establishing the derogating measures as lacking clarity. 
1. Este de principiu că, în împrejurări excepționale, sociale sau naturale, care amenință existența normală a societății, statul poate recurge la măsuri derogatorii privind cele mai multe dintre drepturile omului, adică la limitări excepționale ale acestora, mult mai severe decât cele acceptabile într-o perioadă de normalitate.

Măsurile derogatorii trebuie să aibă un singur scop, și anume rezolvarea situației de criză și revenirea la normalitate, deci ele trebuie să răspundă unei nevoi sociale imperioase, trebuie să fie strict proporționale, limitarea trebuie să fie temeinic motivată, iar aplicarea trebuie să fie nediscriminatorie.

2. Din economia generală a Convenției europene a drepturilor omului și a jurisprudenței Curții Europene a Drepturilor Omului rezultă că una dintre condițiile de validitate a ingerințelor în drepturile omului este ca ingerința să fie prevăzută de "lege".

Noțiunea de "lege" este o noțiune europeană autonomă, semnificând orice sursă a dreptului intern, conform însuși dreptului intern (specificului acestuia). O ingerință într-un drept al omului trebuie să aibă deci un fundament în dreptul național.

Pentru ca o ingerință să satisfacă această condiție de a fi prevăzută de "lege", nu este suficient ca "legea" să existe, ci ea trebuie să îndeplinească și exigențe calitative: să fie accesibilă (destinatarii să o poată cunoaște); să fie previzibilă (să fie suficient de clară, de precisă, pentru ca destinatarii, făcând la nevoie apel la un specialist, să îi poată înțelege conținutul); să prevadă garanții împotriva arbitrariului.

Cerința clarității "legii" se regăsește atât în jurisprudența Curții Europene a Drepturilor Omului, cât și în jurisprudența Curții Constituționale.

Dacă exigența de legalitate există în cazul ingerințelor, adică al limitărilor ordinare ale drepturilor omului, din situațiile obișnuite, a fortiori ea condiționează validitatea măsurilor derogatorii, care sunt limitări mult mai severe ale drepturilor omului, determinate de o situație excepțională, de criză.

3. Condiția previzibilității / clarității "legii" este, conform jurisprudenței instanței de la Strasbourg, mult mai riguroasă în materie "penală" (tot o noțiune europeană autonomă), date fiind consecințele mult mai grave pe care le riscă o 
persoană.

Pentru identitate de rațiune, în opinia noastră, normele dreptului intern ("legea") care decid măsuri derogatorii, deci limitări excepționale, grave, ale drepturilor omului, trebuie să satisfacă un test mai sever de claritate, de rigoare, decât cele care privesc doar ingerințele, adică doar limitările obișnuite ale drepturilor omului.

Dacă normele juridice naționale decizând măsuri derogatorii de la drepturile omului nu au un grad ridicat de claritate, ele nu sunt valide din punct de vedere convențional și constituțional.

4. Ne propunem să verificăm dacă, pe ansamblu, condiția convențională și constituțională de validitate a normelor juridice decizând măsuri derogatorii de la drepturile omului, constând în claritatea / previzibilitatea lor, este respectată în cazul decretelor prin care a fost instituită, apoi prelungită starea de urgență.

Avem în vedere:

- Decretul Președintelui României nr. 195/2020 privind instituirea stării de urgență pe teritoriul României ${ }^{1}$;

- Decretul Președintelui României nr. 240/2020 privind prelungirea stării de urgență pe teritoriul României ${ }^{2}$.

$\mathrm{Ne}$ vom referi la drepturile omului, așa cum sunt ele consacrate de:

- Constituția României ${ }^{3}$;

- Convenția pentru apărarea drepturilor omului și a libertăților fundamentale (Convenția europeană a drepturilor omului) ${ }^{4}$ și Protocoalele adiționale la aceasta ${ }^{5}$;

- Carta socială europeană (revizuită) ${ }^{6}$;

- Carta drepturilor fundamentale a Uniunii Europene ${ }^{7}$;

- Pactul internațional relativ la drepturile civile și politice ${ }^{8}$;

- Pactul internațional relativ la drepturile economice, sociale și culturale ${ }^{9}$.

5. Sub aspectul tehnicii juridice, atât decretul de instituire a stării de urgență, cât și decretul de prelungire a acestei stări rezervă un articol de sine stătător pentru enumerarea drepturilor omului asupra cărora s-au decis măsuri derogatorii.

În ambele decrete este vorba de art. 2.

Articolul conținând enumerarea drepturilor omului vizate de măsurile derogatorii se află chiar la începutul fiecărui decret, imediat după norma 
instituind, respectiv prelungind starea de urgență, ceea ce dovedește importanța materiei, adică importanța măsurilor derogatorii în cazul stării de urgență instituite / prelungite.

6. Drepturile enumerate în art. 2 din cele două decrete sunt în număr de opt și sunt aceleași:

- libera circulație (art. 25 Constituție) / libertatea de circulație (art. 2 P4CEDO; art. 45 CDFUE) / dreptul de a circula liber (art. 12 PIDCP);

- dreptul la viață intimă, familială și privată (art. 26 Constituție) / dreptul la respectarea vieții private și familiale (art. 8 CEDO; art. 7 CDFUE; art. 17 PIDCP);

- inviolabilitatea domiciliului (art. 27 Constituție) / dreptul la respectarea domiciliului (art. 8 CEDO; art. 7 CDFUE; art. 17 PIDCP);

- dreptul la învățătură (art. 32 Constituție); dreptul la educație (art. 14 CDFUE; art. 13 PIDESC);

- libertatea întrunirilor (art. 39 Constituție) / libertatea de reuniune (art. 11 CEDO; art. 12 CDFUE) / dreptul de reuniune (art. 21 PIDCP);

- dreptul de proprietate privată (art. 44 Constituție) / protecția proprietății (art. 1 P1-CEDO) / dreptul de proprietate (art. 17 CDFUE);

- dreptul la grevă (art. 43 Constituție; art. 28 CDFUE) / libertatea sindicală (art. 11 CEDO) / dreptul de grevă (art. 6 CSEr; art. 8 PIDESC);

- libertatea economică (art. 45 din Constituție); libertatea de a întreprinde (art. 16 CDFUE).

În cele două decrete, denumirea acestor drepturi este cea constituțională, denumirile convenționale fiind ușor diferite, așa cum am arătat mai sus.

Cu o singură excepție, și ordinea enumerării drepturilor omului afectate de măsurile derogatorii este aceeași în respectivele două decrete. Excepția este reprezentată de ordinea în cazul ante-penultimului și penultimului drept, care este inversată în decretul de prelungire față de ordinea din decretul de instituire a stării de urgență. Credem că explicația schimbării ordinii enumerării este aceea a respectării ordinii drepturilor din Constituție (ordinea este aceeași cu aceea din Constituție în cazul celui de-al doilea decret), caz în care nu înțelegem motivul pentru care această ordine nu a fost respectată și în primul decret, ci ideea a apărut abia la redactarea celui de-al doilea ${ }^{10}$.

7. Exprimarea utilizată în cele două decrete este:

- "pe durata stării de urgență este restrâns exercițiul următoarelor drepturi" 
(în decretul de instituire);

- "pe durata stării de urgență este restrâns exercițiul următoarelor drepturi și libertăț" (în decretul de instituire).

Sintagma "drepturi și libertățı", folosită în al doilea decret, corespunde terminologiei constituționale.

În mod evident, modul de redactare a textului duce la concluzia că enumerarea expresă este exhaustivă / limitativă. Intenția autorului de grupare a drepturilor vizate într-un singur articol, importanța materiei dovedită prin plasarea textului chiar la începutul actului, forma de exprimare converg către această concluzie.

Ar fi ilogic și contrar normelor de tehnică normativă să existe o enumerare la începutul decretului, dar apoi, în conținutul acestuia, să mai existe drepturi ale omului asupra cărora să poarte măsurile derogatorii.

8. În ciuda concluziei logice și de bun-simț juridic exprimate supra, enumerarea conținută în art. 2 din cele două decrete privitoare la starea de urgență este doar exemplificativă.

Concluzia se impune ca urmare a faptului că, în cuprinsul celor două decrete, sunt și alte drepturi ale omului limitate pe calea măsurilor derogatorii.

Problema este că aceste drepturi, pe lângă faptul că nu sunt incluse în art. 2, nu sunt nominal / expres indicate, concluzia în sensul că sunt limitate prin măsurile derogatorii impunându-se doar în urma analizei detaliate a reglementărilor.

9. În concret, în decretele de instituire și prelungire a stării de urgență, mai fac obiectul măsurilor derogatorii, suplimentar față de drepturile enumerate în art. 2, și următoarele:

- accesul liber la justiție și dreptul persoanei vătămate de o autoritate publică (art. 21 și art. 52 Constituție) / dreptul la un proces echitabil și dreptul la un remediu efectiv (art. 6 și art. 13 CEDO; art. 14 PIDCP) / dreptul la un remediu efectiv și de acces la o instanță imparțială (art. 47 CDFUE);

- libertatea individuală (art. 23 Constituție) / dreptul la libertate și la siguranță (art. 5 CEDO; art. 6 CDFUE) / dreptul la libertate și la securitate (art. 9 PIDCP);

- libertatea de religie (art. 29 Constituție; art. 9 CEDO; art. 10 CDFUE; art. 18 PIDCP); 
- libertatea de exprimare și dreptul la informație (art. 30 și art. 31 Constituție) / libertatea de exprimare (art. 10 CEDO; art. 19 PIDCP) / libertatea de exprimare și de informare (art. 11 CDFUE);

- dreptul la ocrotirea sănătății (art. 34 Constituție) / dreptul la protecția sănătății și dreptul la asistență medicală (art. 11 și art. 13 CSEr) / protecția sănătății (art. 35 CDFUE) / dreptul de a se bucura de cea mai bun stare fizică și mentală (art. 12 PIDESC);

- dreptul la muncă (art. 41 Constituție; art. 1 CSEr; art. 6 PIDESC) / libertatea profesională și dreptul de a munci (art. 15 CDFUE);

- dreptul de petiționare (art. 51 din Constituție).

Vom arăta, pentru fiecare dintre aceste drepturi ale omului în parte, limitările impuse lor de decretele privitoare la starea de urgență, limitări în substanță, fără ca dreptul vizat să fie indicat explicit.

10. Dreptul la un proces echitabil face obiectul măsurilor derogatorii prin:

- Decretul nr. 195/2020, capitolul V, "Domeniul justiție", din anexa nr. 1: suspendarea quasi-integrală a activității instanțelor judecătorești, a parchetelor și a executorilor judecătorești;

- Decretul nr. 240/2020, capitolul VII, "Domeniul justiție", din anexa nr. 1: suspendarea quasi-integrală a activității instanțelor judecătorești, a parchetelor și a executorilor judecătorești.

11. Dreptul la libertate face obiectul măsurilor derogatorii prin:

- Decretul nr. 195/2020, capitolul V, "Domeniul justiție", din anexa nr. 1: suspendarea quasi-integrală a activității instanțelor judecătorești și a parchetelor;

- Decretul nr. 195/2020, pct. 1 din anexa nr. 2:

"Izolarea și carantina persoanelor provenite din zonele de risc, precum și a celor care iau contact cu acestea [...]";

- Decretul nr. 240/2020, pct. 1 din anexa nr. 2:

"Izolarea și carantina persoanelor provenite din zonele de risc, precum și a celor care iau contact cu acestea [...]".

12. Libertatea de religie face obiectul măsurilor derogatorii prin:

- Decretul nr. 240/2020, art. 1 din anexa nr. 1:

"(1) Pe durata stării de urgență se interzic organizarea și desfășurarea: $[\ldots]$; 
b) oricăror altor întruniri de natura activităților [...] religioase [...], în spații închise.

(2) Slujitorii cultelor religioase recunoscute oficial în România pot oficia în lăcașurile de cult, în spații publice sau în spații private:

a) practicile și ritualurile cu caracter public specifice cultului, fără participarea publicului;

b) practicile și ritualurile cu caracter privat specifice cultului, precum botezurile, cununiile sau înmormântările, cu participarea numărului minim de persoane potrivit normelor canonice și cu respectarea strictă a măsurilor de protecție individuală și colectivă pentru prevenirea răspândirii COVID-19."

13. Libertatea de exprimare face obiectul măsurilor derogatorii prin:

- Decretul nr. 195/2020, art. 54 alin. (3), (4) și (5) din anexa nr. 1:

"(3) Furnizorii de servicii de găzduire și furnizorii de conținut sunt obligați ca, la decizia motivată a Autorității Naționale pentru Administrare și Reglementare în Comunicații, să întrerupă imediat, cu informarea utilizatorilor, transmiterea într-o rețea de comunicații electronice ori stocarea conținutului, prin eliminarea acestuia la sursă, dacă prin conținutul respectiv se promovează știri false cu privire la evoluția COVID-19 și la măsurile de protecție și prevenire.

(4) În situația în care eliminarea la sursă a conținutului prevăzut la alin. (3) nu este fezabilă, furnizorii de rețele de comunicații electronice destinate publicului sunt obligați ca, la decizia motivată a Autorității Naționale pentru Administrare și Reglementare în Comunicații, să blocheze imediat accesul la respectivul conținut și să informeze utilizatorii.

(5) La decizia motivată a Autorității Naționale pentru Administrare și Reglementare în Comunicații, furnizorii de rețele de comunicații electronice destinate publicului au obligația de a bloca imediat accesul utilizatorilor din România la conținutul care promovează știri false cu privire la evoluția COVID-19 și la măsurile de protecție și prevenire și este transmis într-o rețea de comunicații electronice de către persoanele de la alin. (3) care nu se află sub jurisdicția legislației naționale.";

- Decretul nr. 195/2020, art. 56 din anexa nr. 1:

"Pe perioada stării de urgență, termenele legale stabilite pentru soluționarea solicitărilor formulate în exercitarea liberului acces la informații de interes public [...] se dublează.";

- Decretul nr. 240/2020, art. 91 alin. (3), (4) și (5) din anexa nr. 1: 
"(1)Furnizorii de servicii de găzduire și furnizorii de conținut sunt obligați ca, la decizia motivată a Autorității Naționale pentru Administrare și Reglementare în Comunicații, să întrerupă imediat, cu informarea utilizatorilor, transmiterea într-o rețea de comunicații electronice ori stocarea conținutului, prin eliminarea acestuia la sursă, dacă prin conținutul respectiv se promovează știri false cu privire la evoluția COVID-19 și la măsurile de protecție și prevenire.

(4) În situația în care eliminarea la sursă a conținutului prevăzut la alin. (3) nu este fezabilă, furnizorii de rețele de comunicații electronice destinate publicului sunt obligați ca, la decizia motivată a Autorității Naționale pentru Administrare și Reglementare în Comunicații, să blocheze imediat accesul la respectivul conținut și să informeze utilizatorii.

(5) La decizia motivată a Autorității Naționale pentru Administrare și Reglementare în Comunicații, furnizorii de rețele de comunicații electronice destinate publicului au obligația de a bloca imediat accesul utilizatorilor din România la conținutul care promovează știri false cu privire la evoluția COVID-19 și la măsurile de protecție și prevenire și este transmis într-o rețea de comunicații electronice de către persoanele de la alin. (3) care nu se află sub jurisdicția legislației naționale.";

- Decretul nr. 240/2020, art. 93 din anexa nr. 1:

"Pe perioada stării de urgență, termenele legale stabilite pentru soluționarea solicitărilor formulate în exercitarea liberului acces la informații de interes public [...] se dublează."

14. Dreptul la protecția sănătății face obiectul măsurilor derogatorii prin:

- Decretul nr. 195/2020, pct. 8 din anexa nr. 2:

"Limitarea activității spitalelor publice la internarea și rezolvarea cazurilor urgente $[\ldots]$ ";

- Decretul nr. 240/2020, pct. 8 din anexa nr. 2:

"Limitarea activității spitalelor publice la internarea și rezolvarea cazurilor urgente $[\ldots]$ ".

15. Dreptul la muncă face obiectul măsurilor derogatorii prin:

- Decretul nr. 195/2020, art. 31 din anexa nr. 1:

"[...] angajați și familiile acestora din sectoarele economice a căror activitate este afectată sau oprită total sau parțial prin decizii ale autorităților publice, pe perioada stării de urgență"; 
- Decretul nr. 195/2020, art. 33 din anexa nr. 1:

"Instituțiile și autoritățile publice centrale și locale, autoritățile administrative autonome, regiile autonome, societățile și companiile naționale și societățile la care statul ori o unitate administrativ-teritorială este acționar unic sau majoritar, societățile cu capital privat introduc, acolo unde este posibil, pe perioada stării de urgență, munca la domiciliu sau în regim de telemuncă, prin act unilateral al angajatorului.";

- Decretul nr. 240/2020, art. 48 din anexa nr. 1:

"Instituțiile și autoritățile publice centrale și locale, autoritățile administrative autonome, regiile autonome, societățile și companiile naționale și societățile la care statul ori o unitate administrativ-teritorială este acționar unic sau majoritar, societățile cu capital privat introduc, acolo unde este posibil, pe durata stării de urgență, munca la domiciliu sau în regim de telemuncă, prin act unilateral al angajatorului. Pe perioada desfășurării activității prin muncă la domiciliu sau telemuncă, salariații își îndeplinesc atribuțiile specifice funcției sau ocupației pe care o dețin, în conformitate cu legislația care reglementează munca la domiciliu și telemunca.";

- Decretul nr. 240/2020, art. 54 din anexa nr. 1:

"Pe durata stării de urgență, în funcție de specificul activității și de nevoi, pentru personalul din sectorul public, angajatorul:

a) poate dispune unilateral întreruperea concediilor de odihnă, de odihnă suplimentare, fără plată, de studii și pentru formare profesională ale personalului angajat și reluarea activității;

b) poate dispune unilateral sau aproba efectuarea totală/parțială a concediului de odihnă sau de odihnă suplimentar al personalului angajat."

16. Dreptul de petiționare face obiectul măsurilor derogatorii prin:

- Decretul nr. 195/2020, art. 56 din anexa nr. 1:

"Pe perioada stării de urgență, termenele legale stabilite pentru soluționarea [...] petițiilor se dublează.";

- Decretul nr. 240/2020, art. 93 din anexa nr. 1:

"Pe perioada stării de urgență, termenele legale stabilite pentru soluționarea [...] petițiilor se dublează."

17. Pe numere mari, aceste șapte drepturi ale omului, vizate doar în substanță, dar nu explicit, de măsurile derogatorii, sunt aceleași în ambele 
decrete.

Excepție notabilă face libertatea de religie, pentru care măsuri derogatorii implicite sunt prevăzute doar în decretul de prelungire a stării de urgență, iar nu și în cel de instituire a acesteia.

18. Se observă că:

- cele mai multe dintre procese nu se judecă, justiția este practic suspendată, dar dreptul la un proces echitabil (incluzând dreptul de acces la o instanță) nu figurează expres printre cele vizate de măsuri derogatorii;

- oamenii pot fi plasați în stare de privare de libertate, fie în carantină instituționalizată, fie în autoizolare la domiciliu, iar cauzele penale (liberări condiționate, contestații la executare - situația conform primului decret) și civile (internări medicale obligatorii, detenția administrativă a străinilor) pot să nu se judece, dar dreptul la libertate nu figurează expres printre cele vizate de măsuri derogatorii;

- s-a interzis credincioșilor participarea la activitățile religioase, dar libertatea de religie nu figurează expres printre cele vizate de măsuri derogatorii;

- mass-media online poate fi închisă, iar termenul de răspuns la cererile de informații de interes public este dublat, dar libertatea de exprimare (incluzând dreptul la informație) nu figurează expres printre cele vizate de măsuri derogatorii;

- accesul la spitalele publice poate fi limitat doar la cazurile urgente, dar dreptul la protecția sănătăți nu figurează expres printre cele vizate de măsuri derogatorii;

- activitatea angajatorilor poate fi oprită total sau parțial de autoritățile publice și aceștia au obligația, dacă este posibil, să impună munca la domiciliu sau în regim de telemuncă, dar dreptul la muncă nu figurează expres printre cele vizate de măsuri derogatorii;

- termenul de răspuns la petiții este dublat, dar dreptul de petiționare nu figurează expres printre cele vizate de măsuri derogatorii.

19. În concluzie, în afară de cele opt drepturi ale omului indicate în mod explicit în cuprinsul propriu-zis al celor două decrete privind starea de urgență (de instituire, respectiv de prelungire) ca făcând obiectul măsurilor derogatorii, deși enumerarea lor indică a fi limitativă, în realitate, fără a fi menționate explicit, încă șapte drepturi ale omului mai formează, în substanță, obiect al măsurilor 
derogatorii, prin anexele la decrete.

Aceste șapte drepturi ale omului sunt extrem de importante: dreptul de acces la justiție și la un proces echitabil; dreptul la libertate; libertatea de religie (numai în decretul de prelungire a stării de urgență); libertatea de exprimare și dreptul la informație; dreptul la protecția sănătății; dreptul la muncă; dreptul de petiționare.

Este evident că, din punct de vedere al criteriului convențional și constituțional al clarității "legii" (normei juridice), măsurile derogatorii privind aceste drepturi, fiind doar implicite și "ascunse" în anexe, în contrast cu o enumerare a drepturilor indicare explicit sub aspectul măsurilor derogatorii, care are pretenția de a fi exhaustivă și care se află în cuprinsul propriu-zis al decretelor și în chiar în partea sa de început, nu trec - în opinia noastră - testul validității convenționale și constituționale.

În opinia noastră, o asemenea tehnică normativă, fie de rea-credință, fie de o neglijență gravă asimilabilă intenției, exprimă un exces manifest de putere al Președintelui României și al Primului-Ministru, cei doi emitenți (semnatarul și contra-semnatarul) ai celor două decrete privind instituirea, respectiv prelungirea stării de urgență.

Nelegalitatea dispozițiilor din cele două decrete privind măsurile derogatorii privitoare la aceste șapte drepturi ale omului atrage, prin contaminare, nelegalitatea actelor administrative inferioare subsecvente, și anume a ordonanțelor militare și a ordinelor secretarului de stat, șef al Departamentului pentru Situații de Urgență, în privința dispozițiilor cuprinse în acestea din urmă care decid măsuri derogatorii vizând aceste drepturi ale omului.

28.04.2020

Materialul a fost publicat în revista online a Facultății de Drept, $\underline{\text { AUBD-Forum }}$ Juridic nr. 1/2020.

\footnotetext{
${ }^{1}$ Publicat în Monitorul Oficial al României, partea I, nr. 212/16.03.2020.

2 Publicat în Monitorul Oficial al României, partea I, nr. 311/14.04.2020.

${ }^{3}$ Republicată în Monitorul Oficial al României, partea I, nr. 767 din 31.10.2003.

${ }^{4}$ În continuare: CEDO.
} 
5 În continuare: Px-CEDO.

${ }^{6}$ În continuare: CSEr.

7 În continuare: CDFUE.

8 În continuare: PIDCP.

9 În continuare: PIDESC.

${ }^{10}$ Probabil că, în timpul primelor 30 de zile ale stării de urgență, lucrând de acasă, vreun funcționar al Departamentului juridic al Administrației Prezidențiale a găsit timpul necesar să citească textul Constituției. 